\title{
Geriatricians, Health Care of the Elderly and the COVID-19 Pandemic
}

\author{
William Arbey Gutiérrez Cortes ${ }^{1 *}$ (D) and Cesar Augusto Rivera Tovar ${ }^{2}$ \\ ${ }^{1}$ Geriatrician and Epidemiologist, Pontifical Javeriana University, Colombia \\ ${ }^{2}$ Physician, Surcolombiana University, Colombia
}

\begin{abstract}
International experience suggests the importance of involving geriatricians in the correct evaluation and management of patients with COVID-19. These patients have adverse results and die due to their advanced age and high comorbidity, so they need doctors capable of dealing with such conditions. The geriatrician is the doctor who knows best the multidimensional approach to the health problems of the elderly, with a great capacity and competence to handle complex and multimorbid patients. Furthermore, the geriatrician is the "guardian" who offers the best possible treatment based on clinical and functional conditions and not only limited to make decisions based on biological age. For health care systems in many countries, it will be crucial to plan as quickly as possible for increased demand of health care and to recognize how to reconfigure services to meet this demand. COVID-19 pandemic has revealed the problem of any health care service in the world. It is important to plan the new hospital infrastructure assuming that the majority of the population can contract the virus with little or no harmful effect, while taking advantage of vital health care resources and experience to treat and manage the percentage of older people who become seriously ill.
\end{abstract}

Keywords

Aging, COVID-19, Geriatricians, Health Care, Pandemic

\section{COVID-19 Impact on Older People in Colombia}

Since the confirmation of the first case of COVID-19 in Colombia on March 6, 2020, the National Government began the implementation of interventions to decrease the Coronavirus contagion rate and the effective reproduction number (Rt), and therefore the mortality rate. When the quarantine was established on March 22, 2020, a Rt of 2.28 was estimated. At that time, evidence showed a world's Rt average range from 2.28 to 5.27 . One of the interventions that the National Government implemented was the mandatory preventive isolation, which imposed mobility restrictions to the general population, with some exceptions including health workers, supply chain personnel and Armed Forces. These measures were effective to implement physical and social distancing which leaded to a significant reduction in the number of cases in the national territory, with a national average Rt of 1.17 by July 20, 2020 [1].

Therefore, the mortality rate has been lower than expected. However, according to the official reports, there has been an increase in the number of cases in the last days. The projections show that we could have new cases until December 2020 [2].

It is important to highlight that in countries where the peak of the epidemic already occurred less than $10 \%$ of the population has antibodies against SARS-CoV-2 (severe acute respiratory syndrome coronavirus 2 ). It means that we are far from the herd immunity, which is achievable, when $40-60 \%$ of the population has antibodies against the virus, depending on the specific Rt present in the different regions [3].

\section{Mortality in Colombia}

By July 20, 2020, there were 197278 reported cases, with 98355 active cases which are the $49 \%$ of the total of confirmed cases. Among the active cases, $88 \%$ are been followed at their homes, $10 \%$ are hospitalized and $1.1 \%$ are in the intensive care unit (ICU). There are also 4927 reported deaths among people over the age of 60 . That means $72 \%$ of all COVID-19-related deaths to date [4] (Table 1).

*Corresponding author: William Arbey Gutiérrez Cortes, Visiting Professor, Surcolombiana University Geriarte, Neiva, Huila, Colombia

Accepted: December 17, 2020

Published online: December 19, 2020

Citation: Cortes WAG, Tovar CAR (2020) Geriatricians, Health Care of the Elderly and the COVID-19 Pandemic. J Geriatr Med 2(1):46-48

Copyright: () 2020 Cortes WAG, et al. This is an open-access article distributed under the terms of the Creative Commons Attribution License, which permits unrestricted use, distribution, and reproduction in any medium, provided the original author and source are credited. 
Table 1: Mortality in people over the age of 60. Data 20/07/2020. Instituto Nacional de Salud (INS).

\begin{tabular}{|l|l|l|}
\hline Age distribution & Number of deaths & $\begin{array}{l}\text { Share of deaths } \\
\text { due to Covid-19 }\end{array}$ \\
\hline $60-69$ years-old & 1.555 & $23 \%$ \\
\hline $70-79$ years-old & 1.760 & $24 \%$ \\
\hline $80-89$ years-old & 1325 & $19 \%$ \\
\hline $90+$ years-old & 377 & $5,6 \%$ \\
\hline Total & 4.927 & $72 \%$ \\
\hline
\end{tabular}

\section{Comorbidities and Risk of Death due to COVID-19}

Recently, the Ministry of Health and Social Protection released the first study of the comorbidities and other factors related to deaths due to COVID-19 in Colombia [5]. The study analyzed 123000 cases from clinical records, which described the risk of death by comorbidities.

Eight conditions were attributed with a higher risk of death. Age is the most important factor. In fact, they found that people over the age of 60 have 19 -fold higher risk of death. This was after they observed that there were 18616 COVID-19 confirmed cases and 3282 fatalities in people around 60-yearsold. The estimation of risk of death was 18.86 . The study also highlighted that among people 70 or over the risk is slightly lower (17.59). This is based on the observed 8691 confirmed cases and 2238 deaths due to COVID-19 [5].

The study shows that having any comorbidity increases the risk of death, 5.94-fold higher than the observed among people without comorbidities. Chronic kidney disease is an important factor related to mortality due to COVID-19, with patients on dialysis having 8.55-fold higher risk of death. 860 of the people who died due to COVID-19 had diabetes, and also 5491 of confirmed cases have this condition, which increases the risk of death, 5.9-fold increase. People with cancer have 4.5-fold higher risk of death due to COVID-19 than healthy people [5].

\section{Deficiencies in Health Care for Older People}

Health of older people is affected in a different way from young adults. This is because disease presentation is different, older people have multiple concomitant pathologies, they take more drugs and the daily living functionality is altered, which may make them depended on other people, thus requiring special assistance [6].

Today, people over the age of 60 are the $13 \%$ of the general population and it is estimated that the $75 \%$ of deaths due to COVID-19 will account for people this age [4].

Geriatric services (inpatient and outpatient services) in Europe and other countries is the cornerstone for the delivery of medical services for older people and it has demonstrated to be cost-effective. Colombia has a historic debt with older people related to their health care, and the COVID-19 pandemic has made it more noticeable.

In 2015, the situation of the geriatrician in Colombia was described. By that time, there were only 51 geriatricians and the study showed the difficulties to practice and to the growth of the specialty in the country [7]. The study highlighted the shortage of geriatricians in Colombia, with only $5 \%$ of the needed doctors to ensure the adequate health care for older people. Older people population is over 5 million in Colombia now [7].

\section{Geriatricians and Their Role in the Health Care for Older People in Colombia}

Geriatrics began in Colombia with a great friendship between two eminent Spanish geriatricians and one geriatrician from Colombia; Dr. Alberto Salgado Alba, founder of the first geriatric department in Spain in 1971 at Hospital Central de la Cruz Roja in Madrid. During 10 years it was the only accredited geriatrics teaching hospital in Spain. Successively, he incorporated the first outpatient services in Spain in 1972, the first domiciliary geriatric service program in 1978 and the first geriatric half-stay unit in 1982. On the other hand, Dr. Francisco Guillén Llera and Dr. Guillermo Marroquín Sánchez, geriatric emintenes who left their mark on the medical practice of their countries and on the academic training of students, some of whom have followed in their footsteps and they have become distinguished modern geriatricians $[8,9]$.

Unfortunately, we observe that even after 40 years of the creation of the specialty in Spain, in Colombia the role of the geriatrician is broadly unknown by the general population yet and there is no universal medical assistance standards for older people; in recent times, we have been leading the construction and design of a public health policy for this population and the specialty has been growing.

\section{Conclusion}

International experience suggests the importance of involving geriatricians in the correct evaluation and management of patients with COVID-19. These patients have adverse results and die due to their advanced age and high comorbidity, so they need doctors capable of dealing with such conditions [10].

First of all, the geriatrician is the doctor who knows best the multidimensional approach to the health problems of the elderly, with a great capacity and competence to handle complex and multimorbid patients. Geriatricians also know best the principles of team working and are capable of adapting the protection measures according to patients' needs in a collaborative relation with other health professionals and families. Furthermore, the geriatrician is the "guardian" who offers the best possible treatment based on clinical and functional conditions and not only limited to make decisions based on biological age $[11,12]$.

COVID-19 pandemic has revealed the problem of any health care service in the world. Older people may lead health and social systems to a critical scenario because these people are not capable of overcoming problems that younger people are. Only the opportune evaluation of the fragility in the community and in the long-term health attention can prevent this systemic crisis, and as a consequence, a new and 
modern health system adapted to the needs of older people is mandatory. It is important to plan the new hospital infrastructure assuming that the majority of the population can contract the virus with little or no harmful effect, while taking advantage of vital health care resources and experience to treat and manage the percentage of older people who become seriously ill $[12,13]$.

\section{Acknowledgments}

\section{Expressions of gratitude}

My eternal thanks to Dr. Carlos Alberto Cano, who was my mentor and professor, to my friends at the Pontificia Universidad Javeriana and to Geriarte.

\section{Conflict of interest}

None.

\section{Sponsor's role}

None.

\section{References}

1. Roselli Diego (2020) Covid-19 en Colombia: Los primeros 90 días. Acta Neurológica Colombiana.

2. Gutiérrez Cortes WA (2020) Papel del geriatra colombiano ante la pandemia por COVID-19. Rev Esp Geriatr Gerontol.

3. Mitja O (2020) Herramientas y estrategias para el desconfin- amiento durante el brote de coronavirus en Cataluña. Fundaciólluita contra la Sida. Generalitat de Cataluña.

4. Boletín Covid 19 En Colombia. INS.

5. La edad y estas enfermedades aumentan el riesgo de morir por covid-19.

6. Marín PP (2007) Reflexiones para considerar en una política pública de salud para las personas mayores. Rev Med Chile 135: 392-398.

7. Gutiérrez William Arbey (2015) Situación actual del médico geriatra en Colombia. 56: 163-177.

8. Cano Carlos A (2008) Francisco guillen llera: un gigante de la geriatría. Desde Colombia. Rev Esp Geriatr Gerontol 43: 41.

9. Torregrossa Roberto Petidier (2008) Francisco Guillén Llera: su legado docente. Rev Esp Geriatr Gerontol 43: 21-22.

10. Haffajee RL, Mello MM (2020) Thinking globally, acting locallydthe U.S. response to COVID-19. N Engl J Med 382: e75.

11. Landi F, Barillaro C, Bellieni A, et al. (2020) The new challenge of geriatrics: Saving frail older people from the SARS-CoV-2 pandemic infection. J Nutr Health Aging 24: e466-e470.

12. Lloyd-Sherlock PG, Kalache A, McKee M, et al. (2020) WHO must prioritise the needs of older people in its response to the covid-19 pandemic. BMJ 368: 1164.

13. Gemelli Against COVID-19 Geriatrics Team, Francesco Landi, Christian Barillaro, et al. (2020) The Geriatrician: The Frontline Specialist in the Treatment of COVID-19 Patient. JAMDA 21: 937e938.

DOI: $10.36959 / 452 / 581$ 